\title{
Penerapan Diversi Pada Penyidikan Perkara Anak
}

\section{Application of Diversion in Investigating Child Cases}

\author{
Ari Saputra
}

ari_27394@yahoo.com

Kejaksaan Negeri Tanggamus di Talang Padang

Submitted: Mar 16, 2020; Reviewed: Mar 31, 2020; Accepted: Apr 20, 2020

\begin{tabular}{ll}
\hline Info Artikel & Abstrak
\end{tabular}

Kata Kunci: Diversi; Anak.

Keywords: Diversion; Child..

DOI:

https://doi.org/10.25041/ip.v1i1.2052

\begin{abstract}
Instrument diversi yang diterapkan di masyarakat selain memberikan manfaat, akan tetapi tidak menutup kemungkinan juga terdapat kelemahannya. Dalam sistem peradilan pidana anak, tentunya anak mendapat kekhususan mengenai penyidiknya. Bahwa yang berhak menyidik anak adalah penyidik yang memiliki pengalaman dan dedikasinya untuk anak, sebab diversi tersebut tidak semudah yang dibayangkan dalam pelaksanaannya khususnya di daerah-daerah terpencil. Adapun yang menjadi fokus dalam penulisan jurnal ini adalah bagaimanakah kebijakan penerapan diversi pada penyidikan perkara anak dan apa dampak atau akibat hukum diversi dalam rangka memberikan hak-hak anak yang berhadapan dengan hukum. Metode yang di gunakan dalam penulisan ini adalah metode dengan pendekatan secara yuridis normatif. Berdasarkan hasil penelitian dan pembahasan maka dapat diketahui bahwa efektivitas kebijakan diversi penyidik dalam rangka menyelamatkan masa depan anak pada kenyataannya dilapangan masih jauh kata efektif karena tidaklah mudah untuk melaksanakan diversi tersebut. Fakta dilapangan bahwa pelaksanaan diversi masih memiliki kendala
\end{abstract}


teknis seperti kesulitan korban menandatangani kesepakatan perdamaian sebagai salah satu syarat non yuridis yang selama ini dipersyaratkan dalam diversi, sehingga pelaksanaan diversi gagal dilakukan. Kurangnya pemahaman dari masyarakat tentang diversi, hal ini berpotensi menimbulkan public complain dari masyarakat, dan dampak atau akibat hukum diversi yakni dapat menghindari stigmatisasi buruk terhadap anak dan mampu memberikan penyelesaian alternatif berupa pengesampingan hukuman pidana karena secara fungsinya diversi memberikan win-win solution. Berdasarkan uraian diatas maka yang menjadi saran penulis adalah: Sebaiknya Polri lebih mengefektifkan perannya dalam melaksanakan upaya diversi kepada anak yang berhadapan dengan hukum sehingga citra penegakan hukum polri tidak mengutamakan penghukuman semata akan tetapi lebih mencari win-win solution bagi anak. Sebaiknya pihak korban menghilangkan sikap egosentris dan dendam kepada pihak tersangka anak sehingga agar pelaksanaan diversi dapat terwujud dengan baik.

Abstract
Inversion instrument that is applied in the
community in addition to providing benefits, but
does not rule out there are also weaknesses. So
far, diversion policies are still very little carried
out in the regions even though diversion is
mandatory. In the juvenile justice system, of
course, children get specificity about the
investigator. Whereas those who have the right
to investigate children are investigators who
have experience and dedication for children,
because the diversion is not as easy as imagined
in its implementation, especially in remote
areas. As for the focus in writing this journal is
how the policy of application of diversion in the
investigation of cases of children and what the
impact or consequences of diversion in order to
provide the rights of children who are in conflict
with the law. The method used in this paper is a
method with a juridical approach to Empirical
and Normative Juridical. Based on the results of
research and discussion, it can be seen that the
effectiveness of the policy of diversion of
investigators in order to save the future of
children is actually far from effective in the field


because it is not easy to implement the diversion. The facts on the ground that the implementation of diversion still has technical constraints such as the difficulty of victims signing a peace agreement as one of the nonjuridical conditions that has been required in the diversion, so that the implementation of the diversion failed to do. Lack of understanding from the public about diversion, this has the potential to cause public complaints from the public, and the impact or legal consequences of diversion that can avoid bad stigmatization of children and be able to provide alternative solutions in the form of criminal penalties because the function of diversion is to provide a win-win solution. Based on the description above, the writer's suggestion is: It is better for the National Police to be more effective in carrying out diversionary efforts to children who are dealing with the law so that the image of police law enforcement does not prioritize punishment alone but rather seeks a win-win solution for children. The victim should eliminate the egocentric and vengeful attitude towards the suspect child so that the diversion can be carried out properly.

\section{A. Pendahuluan}

Pada dasarnya hukum adalah pencerminan dari Hak Asasi Manusia (HAM), sehingga hukum itu mengandung keadilan atau tidak akan ditentukan oleh HAM yang terkandung dan juga diatur atau dijamin dalam hukum tersebut. Hukum tidak akan lagi dilihat sebagai cerminan dari kekuasaan semata-mata, namun juga harus mencerminkan perlindungan terhadap hak-hak para warga negara. ${ }^{1}$ Faktor yang mempengaruhi anak melakukan tindak pidana biasanya adalah faktor lingkungan dan pengaruh budaya buruk yang sedang marak berasimilasi dalam tata kehidupan saat ini turut mempengaruhi anak menjadi pelaku kejahatan. Dalam menyikapi anak yang terlibat kasus kejahatan tidak bisa sembarangan memberikan sanksi pidana terhadap anak tersebut diperlukan pendekatan khusus yakni yang dikenal bernama restorative justice system. ${ }^{2}$

Melihat kondisi sifat yang khas pada anak dan demi perlindungan terhadap anak, perkara anak yang berhadapan dengan hukum wajib disidangkan di pengadilan anak yang berada dilingkungan peradilan umum. Munculnya Restorative Justice karena proses pidana belum memberikan keadilan pada korban. Restorative Justice menempatkan sebuah kejahatan sebagai suatu gejala yang menjadi bagian tindakan sosial dan bukan sekedar pelanggaran hukum pidana atau kejahatan yang dipandang sebagai perusak hubungan sosial. ${ }^{3}$ Proses

\footnotetext{
${ }^{1}$ Eka Intan Putri, "Begal Anak; Pemenuhan Hak dan Lembaga Pembinaan Khusus Anak Kelas II A Bandar Lampung", Jurnal Cepalo, 2 (2), (2018).

${ }^{2}$ Nashriana, Perlindungan Hukum Pidana Bagi Anak di Indonesia, Raja Grafindo Persada, Jakarta, 2011, hlm 1

${ }^{3}$ Reyner Timothy Danielt, "Penerapan Restorative Justice Terhadap Tindak Pidana Anak Pencurian Oleh Anak Di Bawah Umur." Jurnal Lex Et Societatis. Vol. Ii. No. 6 (2014). hlm. 16.
} 
peradilan perkara anak sejak ditangkap, ditahan, dan diadili pembinaannya wajib dilakukan oleh pejabat khusus yang memahami masalah anak. ${ }^{4}$ Keadilan dalam Restorative adalah istilah yang sering digunakan terhadap pendekatan dalam system peradilan pidana yang lebih focus pada korban dan masyarakat, dibandingkan dengan memidana pelaku. ${ }^{5}$ Tujuan dibentuknya instrument restorative justice system tidak lain adalah guna memberikan penyelesaian secara non penal tanpa menggunakan hukuman dan sanksi pidana terhadap anak, yang mana penyelesaian melalui instrument restorative justice system ini adalah salah satu bentuk penyelesaian yang efektif tanpa harus melibatkan aparat penegak hukum yang jelas akan mempengaruhi psikologis anak ketika berhadapan dengan hukum. ${ }^{6}$ Prinsip utama pelaksanaan konsep diversi ialah pendekatan persuasif atau pendekatan non penal dan memberikan kesempatan kepada sesorang untuk memperbaiki kesalahan. ${ }^{7}$

Penyelenggaraan sistem peradilan pidana anak melalui instrument restorative justice system, bertujuan meningkatkan kesejahteraan dan perlindungan terhadap masa depan anak. Hal ini sebagaimana ditegaskan dalam peraturan Perserikatan Bangsa-Bangsa, yang menyatakan bahwa "Sistem peradilan pidana bagi anak atau remaja akan mengutamakan kesejahteraan remaja dan memastikan bahwa reaksi apapun terhadap pelanggar-pelanggar hukum berusia remaja akan selalu sepadan dengan keadaan-keadaan baik pada pelanggarpelanggar hukum maupun pelanggaran hukumnya."

Bentuk perwujudan restorative justice system yang dikenal dengan diversi tidak lain adalah untuk menjaga dan melindungi harkat dan martabat anak. dari pengaruh buruk stigmatisasi hukum yang nantinya membuat masa depan anak tersebut terganggu akibat dari pelaksanaan hukum itu sendiri. Penjara bukanlah sarana yang tepat untuk memberikan sanksi terhadap anak yang berhadapan dengan hukum. ${ }^{8}$ Restorative justice merupakan suatu proses diversi, yaitu semua pihak yang terlibat dalam suatu tindak pidana tertentu bersama-sama mengatasi masalah serta menciptakan suatu kewajiban untuk membuat segala sesuatunya menjadi lebih baik dengan melibatkan korban, pelaku, dan masyarakat dalam mencari solusi untuk memperbaiki, rekonsiliasi, dan menenteramkan hati yang tidak berdasarkan pembalasan. ${ }^{9}$ Pendekatan Restorative Justice merupakan suatu paradigma yang dapat dipakai sebagai bingkai dari strategi penanganan perkara pidana yang bertujuan menjawab ketidakpuasan bekerjanya sistem peradilan pidana yang ada saat ini yang sedang terjadi. ${ }^{10}$

Diversi merupakan proses melimpahkan anak pelaku tindak pidana dari sistem peradilan pidana kepada sistem informal seperti mengembalikan kepada lembaga social masyarakat, baik pemerintah negara maupun non pemerintah. Tindakan ini dilakukan untuk menghindari efek negative terhadap jiwa dan perkembangan anak. ${ }^{11}$ Bentuk-bentuk hasil kesepakatan diversi antara lain dapat berupa perdamaian dengan atau tanpa ganti kerugian, penyerahan kembali kepada orang tua/wali, keikutsertaan dalam pendidikan atau pelatihan di lembaga

\footnotetext{
${ }^{4}$ Teguh Prasetyo, "Penerapan Diversi Terhadap Tindak Pidana Anak Dalam Sistem Peradilan Pidana Anak.” Jurnal Refleksi Hukum. Vol. 1. No. 9 (2015).

${ }^{5}$ I Tajudin \& Nella Sumika Putri, "Penyelesaian Tindak Pidana Lalu Lintas Melalui Pendekatan Restorative Justice Sebagai Dasar Penghentian Penyidikan dan Perwujudan Asas Keadilan dalam Penjatuhanh Putusan.” Jurnal Padjajaran Ilmu Hukum. Vol. 2. No. 1 (2015).

${ }^{6}$ Mayasari, Implementasi Diversi Terhadap Pelaku Tindak Pidana Anak", Skripsi, Fakultas Syari'ah dan Hukum, Universitas Islam Negeri Sunan Kalijaga Yogyakarta, 2015, hlm. 1.

${ }^{7}$ Randy Pradityo, "Restorative Justice Dalam Sistem Peradilan Pidana Anak." Jurnal Hukum Dan Peradilan. Vol. 5. No. 3 (2016).

${ }^{8}$ Setya Wahyudi, Implementasi Ide Diversi dalam Pembaharuan Sistem Peradilan Anak di Indonesia, Genta Publising, Yogyakarta, $2011 \mathrm{hlm} .2$.

${ }^{9}$ Dwi Ratna Kamala Sari Lukman, "Konsep Restorative Justice Dalam Undang-Undang Ri Number 11 Tahun 2012 Tentang Sistem Peradilan Pidana Anak.” Jurnal Ius Kajian Hukum Dan Keadilan. Vol. 2. No. 6 (2016)

${ }^{10}$ Ulang Mangun Sosiawan, "Perspektif Restorative Justice Sebagai Wujud Perlindungan Anak Yang Berhadapan Dengan Hukum.” Jurnal Penelitian Hukum De Jure. Vol. 16. No. 4 (2016).hlm. 426.

${ }^{11}$ Made Ayu Citra Maya Sari, "Diversi Dalam Sistem Peradilan Pidana Anak Di Indonesia." Udayana Master Law Journal. Vol. 2. No. 1 (2013).
} 
pendidikan atau LPKS paling lama 3 (tiga) bulan, pelayanan masyarakat. ${ }^{12}$ Guna menjawab seluruh permasalahan dan tantangan tersebut, yakni ditempuh dengan menggunakan pendekatan restorative justice system yang dilaksanakan dengan cara mekanisme diversi. Cara tersebut menjadi prioritas dalam menyelesaikan perkara anak. ${ }^{13}$ Untuk memecahkan masalah dan memikirkan bagaimana mengatasi akibat pada masa yang akan datang. Proses ini pada dasarnya dilakukan melalui diskresi (kebijakan) dan diversi (pengalihan dari proses pengadilan pidana ke luar proses formal untuk diselesaikan secara musyawarah). ${ }^{14}$ Pemberian perlakuan khusus dalam rangka menjamin pertumbuhan fisik serta mental anak sebagai generasi penerus yang harus diperhatikan masa depannya, dimana dalam hal ini memberikan suatu keadilan, hakim melakukan berbagai tindakan dengan menelaah terlebih dahulu tentang kebenaran peristiwa yang diajukan kepadanya. ${ }^{15}$ Restorative Justice terwujud ketika perdamaian dan rekonsiliasi antara korban, pelaku dan masyarakat terwujud atau dipulihkan, ${ }^{16}$ perdamaian dan rekonsialiasi selaras dengan budaya masyarakat Indoensia yang lebih mengedepankan musyawarah yang menjadi ciri khas bangsa Indonesia dalam menghadapi suatu permasalahan.

Undang-Undang Nomor 35 Tahun 2014 perubahan atas Undang-Undang Nomor 23 Tahun 2002 tentang Perlindungan Anak menguraikan pasal demi pasal mengenai perlindungan anak yang pada pokoknya bertujuan untuk memberikan jaminan dan melindungi hak-hak anak. ${ }^{17}$ Perlindungan hukum terhadap anak menjadi masalah serius yang harus dicarikan jalan keluarnya mengingat anak menjadi aset bangsa yang harus mendapat perlindungan secara komperhensif. ${ }^{18}$ Berbicara mengenai perlindungan terhadap anak memang menyangkut aspek yang sangat luas dikarenakan terdapat beberapa elemen krusial mengingat masa depan anak adalah hal yang sangat penting. ${ }^{19}$ Pendapat yang pro terhadap pelaksanaan diversi adalah mengingat hukum pidana formal dirasa tidak efektif untuk memberikan efek jera kepada anak yang berhadapan dengan hukum. Mengingat sanksi hukuman hanya memberikan cap buruk dan kriminal dimata masyarakat. Pendapat yang kontra terhadap diversi yakni dengan berbagai Pertama, dikuatirkan tidak memberikan efek jera dan menjadi dalih agar bisa terlepas dari jeratan hukum karena adanya kebijakan diversi, jika anak salah memaknai maka hal tersebut akan menambah daftar panjang anak yang berhadapan dengan hukum di Indonesia.Seperti contoh kasus anak dilakukan diversi yakni dengan atas nama Terdakwa Reza Fernando dan Riko Aprian yang mana dalam hal ini mereka berdua diduga melakukan tindak pidana pencurian dalam Pasal 363, 365 KUHP yang mana majelis hakim melakukan penetapan terhadap keduanya yang masing-masing dengan nomor Putusan Nomor 07/Pid.SusAnak/2018/PN.Kot dan 10/Pid.Sus-Anak/2018/PN. Kot., akan tetapi setelah dilakukan diversi dua tahun kemudian anak tersebut melakukan tindak pidana yang sama (recidivies). sehingga penerapan diversi pun tidak berpengaruh apa-apa dan tidak memberikan efek kesadaran.

Berdasarkan latar belakang tersebut penulis tertarik untuk melakukan penelitian jurnal dengan judul "Kebijakan Penerapan Diversi Pada Penyidikan Perkara Anak".

\footnotetext{
${ }^{12}$ Alex Andreas, Toria Pujiono \& Nur Rochaeti, “Implementasi Restorative Justice Dalam UU No 11 Tahun 2012 Tentang Sistem Peradilan Pidana Anak. Diponegoro Law Journal. Vol. 5. No. 3 (2016).

${ }^{13}$ Nandang Sambas, Pembaruan Sistem Pemidanaan Anak di Indonesia, Graha Ilmu, Yogyakarta, 2010, hlm. 25.

${ }^{14}$ Renita Dharma Pratiwi, Moch. Ardi, \& Rosdiana, "Kendala Penerapan Prinsip Restorative Justice Dalam Perkara Tindak Pidana Anak." Jurnal Lex Suprema. Vol. 1. No. 2 (109).hlm. 5.

15 Pangestika Rizki Utami, "Konsep Diversi Dan Restorative Justice Sebagai Pergeseran Tanggung Jawab Pidana Pada Sistem Peradilan Pidana Anak.” Volksgeist: Jurnal Ilmu Hukum Dan Konstitusi. Vol. 1 No. 1 (2018). Hlm. 99.

${ }^{16}$ Iwan Hertanto, "Penegakan Hukum Tindak Pidana Ringan Oleh Polri Melalui Pendekatan Restorative Justice (Studi Di Wilayah Hukum Polres Cilacap).” Jurnal Idea Hukum. Vol. 4. No. 1 (2018). hlm 898

${ }^{17}$ Muhadar, Abdullah, Husni Thamrin, Perlindungan Saksi dan Korban dalam Sistem Peradilan Pidana, Cv Putra Media Nusantara, Surabaya, 2009, hlm. 74.

${ }^{18} \mathrm{Ibid}$, hlm. 76.

${ }^{19}$ Waluyadi, Hukum Perlindungan Anak, Mandar Maju, Bandung, 2009, hlm. 1.
} 


\section{B. Rumusan Masalah}

Berdasarkan uraian latar belakang di atas, maka yang menjadi rumusan masalah adalah:

1) Bagaimanakah kebijakan penerapan diversi pada penyidikan perkara anak ?

2) Bagaimankah dampak atau akibat hukum diversi rangka memberikan hak-hak anak yang berhadapan dengan hukum?

\section{Hasil Penelitian Dan Pembahasan}

\section{Kebijakan Penerapan Diversi Pada Penyidikan Perkara Anak}

Menurut pandangan restroative justice, penagnanan kejahatan yang terjadi tidak hanya menjadi tanggung jawab negara akan tetapi juga merupakan tanggung jawab masyarakat. Oleh karena itu, konsep restorative justice di bnagun berdasarkan pengertian kerugian yang ditimbulkan oleh kejahatan akan dipulihkan kembali, baik kerugian yang diderita oleh korban maupun kerugian yang ditangung oleh masyarakat. ${ }^{20}$ Penerapan diversi dilakukan dengan proses yang sangat selektif dengan melihat pertimbangan yang cermat. Adapun berbagai syarat dalam pelaksanaan diversi yang mengacu pada Undang-undang Sistem Peradilan Pidana Anak. Tentunya terdapat berbagai kategori tindak pidana yang tidak dapat dilakukan diversi. mencakup hal berikut:

1) Melihat usia pelaku

Syarat penting usia menjadi hal penting yang harus diperhatikan. Usia menjadi standar tolak ukur untuk dapat dilakukan diversi terhadap anak. Penggolongan usia anak wajib diperhatikan oleh penegak hukum hal ini bukan saja menyangkut syarat dan ketentuan di undang-undang akan tetapi turut mempengaruhi psikologi anak dalam melakukan tindak pidana, hal tersebut diatur dalam Pasal 1 ayat 3 Undang-undang Nomor 11 Tahun 2012 Tentang Sistem Peradilan Pidana Anak. Dengan dasar hukum yang menyatakan bahwa penanganan kasus yang melibatkan anak di bawah umur harus menerapkan tindakan diversi. Penerapan diversi diharapkan dapat menjadi solusi terbaik dalam penerapan hukum bagi anak yang terlibat dalam kasus tindak pidana. ${ }^{21}$

\section{2) Mengakui Kesalahan dan Bersedia Untuk Dilakukan Diversi}

Anak yang melakukan tindak pidana sedianya harus kooperatif dalam memberikan pernyataan bersalahnya di depan penegak hukum dan juga korban. Hal tersebut menjadi syarat bahwa sedianya anak harus membuat penyataan bersalah dan kesediannya untuk dilakukan diversi. Pentingnya pengakuan kejujuran dari anak yang melakukan tindak pidana tersebut menunjukan bahwa upaya diversi ini bukan hanya formalitas yang harus dipenuhi semata, karena upaya diversi tersebut adalah wujud penyelesaian masalah melalui pola kekeluargaan sehingga nantinya terdapat titik penyelesaian yang terbaik untuk menjamin masa depan anak.

\section{3) Adanya Kesepakatan dan Keikhlasan dari Pihak Korban}

Korban menurut Pasal 1 angka 2 Undang-Undang Nomor 13 tahun 2006 tentang Perlindungan Saksi dan Korban adalah orang yang mengalami penderitaan, fisik, mental,

\footnotetext{
${ }^{20}$ Irma Cahyaningtyas, “Pembinaan ANAKA Pidana di Lembaga Pembinaan Khusus Anak Dalam Presfektif restotarive justice.” Jurnal Notaris. Vol. 8. No 2 (2015).

${ }^{21}$ Pendi Wibison, "Penerapan Tindakan Diversi Dalam Proses Penyidikan Tindak Pidana Terhadap Tersangka Anak Di Polres Sukoharjo (Studi Kasus An. Ricky Hernawan),” accessed July 8, 2020, http://journal.akpol.ac.id/index.php/apsrj/article/view/108/66.hlm. 1718
} 
dan/atau kerugian ekonomi yang diakibatkan oleh suatu tindak pidana. ${ }^{22}$ Korban merupakan pihak yang dirugikan oleh perbuatan yang dilakukan oleh pelaku. Korban secara materil memang sangat dirugikan akibat dari adanya suatu tindak pidana yang dilaukan oleh pelaku tersebut. Hal inilah yang menjadi point penting untuk dapat diterimanya proses diversi tersebut, tidak menutup kemungkinan korban akan melakukan tindakan balas dendam dan enggan memaafkan korban, maka syarat diversi tersebut memang harus sedianya memperhatikan aspek dari keikhlasan korban untuk memaafkan pelaku, maka dengan memperhatikan hal tersebut persetujuan dari pihak korban memang sangat dibutuhkan dalam menyelesaikan tindak pidana tersebut, dengan adanya persetujuan dari pihak korban tentunya akan mempermudah proses diversi itu sendiri sehingga para pihak tidak ada yang dirugikan dalam hal ini.

Dikaji dari teori efektivitas hukum, berdasarkan penelitian ini akan menguraikan satu persatu efektivitas hukumnya:

1) Faktor hukumnya sendiri (undang-undang)

Faktor hukumnya berarti peneliti melihat tidak ada yang perlu diperdebatkan berkenaan dengan undang-undangnya dikarenakan undang-undang Sistem Peradilan Pidana Anak justru sangat membantu dalam menyelamatkan masa depan anak yang berhadapan dengan hukum karena ada instrument diversi

2) Faktor penegak hukum

Menurut peneliti apabila dilihat faktor penegak hukumnya memang peneliti melihat di daerah-daerah terpencil memang sangat sulit menemukan penyidik anak mengingat penyidik yang melakukan penyidikan anak haruslah penyidik yang berpengalaman dalam hal melakukan penyidikan khususnya mengenai pemeriksaan anak karena di daerah terpencil sendiri memang sangat sedikit sekali SDM yang menguasai pemeriksaan terhadap anak. Alhasil pemeriksaan anak pun digabung menjadi satu dalam pemeriksaan tingkat dewasa.

3) Faktor sarana atau fasilitas

Menurut peneliti apabila dilihat dari faktor sarana dan fasilitas bahwa di dapati khususnya di polsek tidak terdapat unit Divisi Perlindungan Perempuan dan Anak sehingga terjadi penumpukan perkara di Polres terkait masalah anak yang berhadapan dengan hukum tersebut sehingga secara fasilitas belum memadai di tingkat tataran polsek sehingga tidak efektif untuk dilaksanakan.

4) Faktor masyarakat

Masyarakat belum bisa menerima instrument diversi khsuusnya bagi korban sehingga ketika pihak korban dan pelaku ketika hendak berdamai pihak korban enggan melakukan Kesepakatan kepada pihak Tersangka. Seringkali terjadi kendala teknis ketika penyidik menilai bahwa perkara yang ditangani dapat dilakukan Diskresi, tetapi antara pihak korban dengan pihak tersangka belum ada suatu kesepakatan perdamaian sebagai salah satu syarat non yuridis yang selama ini dipersyaratkan dalam diversi.

Dalam pelaksanaan Ganti Rugi terhadap korban, sering kali penentuan kesepakatan ganti rugi tidak dapat disanggupi oleh pihak anak yang berhadapan dengan hukum. padahal pada prinsipnya bahwa terlaksananya diversi sangat di pengaruhi oleh kesediaan pihak anak yang berhadapan dengan hukum, untuk memberi ganti rugi kepada pihak korban dan hal ini tidaklah mudah, sehingga menyebabkan ketidak efektifan dalam pelaksanaanya.Ditambah lagi masyarakat menilai kebijakan diversi ini sangat memberatkan khususnya bagi pihak korban. Kurangnya pemahaman dari masyarakat tentang diversi, hal ini akan berpotensi menimbulkan public complain dari masyarakat.

${ }^{22}$ Miszuarty Putri, "Pelaksanaan Restitusi Bagi Anak Yang Menjadi Korban Tindak Pidana Sebagai Bentuk Pembaruan Hukum Pidana Berdasarkan Peraturan Pemerintah Nomor 43 Tahun 2017," Soumatera Law Review 2, no. 1 (May 1, 2019): 115-34, https://doi.org/10.22216/soumlaw.v2i1.3567.g1347.hlm. 118. 
5) Faktor kebudayaan

Hukum dan kebudayaan memiliki kausalitas sebagai fungsi kontrol terhadap masyarakat, hal ini berarti hukum sangat dipengaruhi oleh faktor-faktor non hukum seperti: nilai, sikap, dan pandangan masyarakat yang biasa disebut dengan kultur/budaya hukum. ${ }^{23}$ Penerapan konsep Diversi banyak disalah artikan sehingga ditakutkan akan menjadi celah bagi pelaku kejahatan yang mempergunakan anak sebagai subyek pelaku kejahatan. Dikhawatirkan dengan berlakunya Undang-Undang Nomor 11 Tahu 2012 tentang Sistem Peradilan Pidana Anak ini jumlah anak pelaku tindak pidana semakin meningkat karena tidak khawatir dikenai sanksi hukuman penjara karena adanya kebijakan diversi, jika anak salah memaknai maka hal tersebut akan menambah daftar panjang anak yang berhadapan dengan hukum di Indonesia.

Seperti contoh kasus anak dilakukan diversi yakni dengan atas nama Terdakwa Reza Fernando dan Riko Aprian yang mana dalam hal ini mereka berdua diduga melakukan tindak pidana pencurian dalam Pasal 363, 365 KUHP yang mana majelis hakim melakukan penetapan terhadap keduanya yang masing-masing dengan nomor Putusan Nomor 07/Pid.SusAnak/2018/PN.Kot dan 10/Pid.Sus-Anak/2018/PN. Kot., akan tetapi setelah dilakukan diversi dua tahun kemudian anak tersebut melakukan tindak pidana yang sama (recidivies). sehingga terhadap pelaksanaannya menjadi tidak efektif dan tidak menimbulkan efek jera

\section{Dampak atau Akibat Hukum Diversi Rangka Memberikan Hak-Hak Anak yang Berhadapan dengan Hukum}

Sebagai konsekuensinya dengan diundangkannya Undang-Undang Nomor 11 Tahun 2012 tentang Sistem Peradilan Anak yang menganut konsep diversi bagi anak memiliki dampak/akibat hukum menghindari dan menjauhkan anak dari proses peradilan, sehingga dapat menghindari stigmatisasi buruk dari kesan pelaku kriminal. Sebagai wujud untuk menghilangkan stigmatisasi anak dari citra buruk karena memperoleh hukuman. untuk itu pemerintah mengeluarkan Undang-Undang Nomor 11 Tahun 2012 tentang Sistem Peradilan Pidana Anak hal ini sebagai wujud penerapan konsep restoratif justice yang mana konsep ini penting untuk menyelamatkan masa depan anak. Sebagai wujud implementasinya adalah dibentuk program diversi hal ini sangat berguna bagi anak yang melakukan tindak pidana agar terhindar dari pengaruh buruk penjara yang justru akan mengabaikan hak-hak anak yang dijamin oleh undang-undang.

Efek dari dilakukannya diversi ini tentunya memberikan keuntungan bagi masa depan anak dan juga tentunya hak anak akan menjadi terlindungi secara hukum. kemudian dapat meneruskan masa depannya, terhindar dari pengaruh buruk baik secara materil dan moril akibat dikenakan sanksi pidana penjara tersebut. Pengesampingan sanksi pidana tersebut bukan semata-mata anak kebal dengan hukum (imunitas) tentunya hal tersebut adalah persepsi yang salah karena diversi tersebut sebagai wujud penyelesaian masalah dengan cara non litigasi dengan mempertemukan kedua belah pihak antara pelaku dan korban guna mencari jalan keluar untuk melakukan mediasi demi kepentingan bersama.

Sebagaimana dikaitkan dengan teori perlindungan hukum Menurut pendapat Phillipus M. Hadjon bahwa perlindungan hukum bagi rakyat sebagai tindakan pemerintah yang bersifat preventif dan represif yang mana perlindungan keduanya tersebut dimaksudkan untuk melindungi masyarakat dari tindakan yang merugikan. ${ }^{24}$

Berdasarkan penelitian yang peneliti temui diversi cukup memberikan dampak yang positif bagi anak khususnya terhadap jiwa, perlindungan dan masa depannya hal ini dikarenakan konsep ini lebih dititik beratkan pengembalian kerugian baik secara materil maupun imateril,

\footnotetext{
${ }^{23}$ Yusi Permatasari, Yuwono Prianto. "Kendala Dalam Pelaksanaan Penegakan Hukum Terhadap Praktik Paranormal Sebagai Tindak Pidana." Jurnal Hukum Adigama. Vol. 2. No. 2 (2019).

${ }^{24}$ Phillipus M. Hadjon, Perlindungan Hukum Bagi Rakyat Indonesia, PT. Bina Ilmu, Surabaya: 1987. hlm.29.
} 
dan juga menekan angka over capacity penjara. Penerapan diversi ini memberikan pemahaman juga tentunya kepada masyarakat mengingat kualifikasi tindak pidana dibagi dalam dua kategori yakni tindak pidana yang dilakukan oleh orang dewasa tentunya sanksinya harus ditanggulangi dengan cara menerapkan sanksi pidana dan kedua adalah tindak pidana yang dilakukan oleh anak yang disebut kenakalan remaja tentunya sanksinya tidak dapat dikenakan sanksi pidana, tetapi harus dilakukan dengan pendekatan restoratif justice dengan cara melalui program diversi.

\section{Penutup}

Berdasarkan hasil penelitian dan pembahasan tersebut di atas, maka penulis menarik kesimpulan sebagai berikut:

1. Kebijakan penerapan diversi pada penyidikan perkara anak yang berhadapan dengan hukum sejak diundangkannya Undang-Undang Sistem Peradilan Pidana Anak memiliki pengaruh besar dalam memberikan solusi bagi anak yang yang berhadapan dengan hukum pelaksanaanya dilapanganpun masih jauh kata efektif karena tidaklah mudah untuk melaksanakan diversi tersebut kenyataannya dilapangan bahwa pelaksanaan diversi masih memiliki kendala teknis seperti enggannya korban menandatangani kesepakatan perdamaian sebagai salah satu syarat non yuridis yang selama ini dipersyaratkan dalam diversi, sehingga pelaksanaan Diversi gagal dilakukan. dan juga kurangnya pemahaman dari masyarakat tentang Diversi, hal ini akan berpotensi menimbulkan public complain dari masyarakat.

2. Dampak/akibat hukum diversi rangka memberikan hak-hak anak yang berhadapan dengan hukum Sebagai konsekuensinya dengan diundangkannya Undang-Undang Sistem Peradilan Anak yang menganut konsep diversi bagi anak memiliki dampak/akibat hukum memberikan alternatif penyelesaian yang baik diluar pemidanaan sehingga menghilangkan stigmatisasi buruk perilaku kriminal terhadap diri anak.

\section{Daftar Pustaka}

A. Buku.

Achmad Ali, Menguak Teori Hukum dan Teori Peradilan Vol.1, Kencana, Jakarta, 2010.

Dwidja Priyatno, Wajah Hukum Pidana Asas dan Perkembangan, Gratama Publishing, Bekasi, 2012.

Mayasari, Implementasi Diversi Terhadap Pelaku Tindak Pidana Anak", Skripsi, Fakultas Syari'ah dan Hukum, Universitas Islam Negeri Sunan Kalijaga Yogyakarta, 2015.

Muhadar, Abdullah, Husni Thamrin, Perlindungan Saksi dan Korban dalam Sistem Peradilan Pidana, Cv Putra Media Nusantara, Surabaya, 2009.

Nandang Sambas, Pembaruan Sistem Pemidanaan Anak di Indonesia, Graha Ilmu, Yogyakarta, 2010.

Nashriana, Perlindungan Hukum Pidana Bagi Anak di Indonesia, PT Raja Grafindo Persada, Jakarta, 2011.

Phillipus M. Hadjon, Perlindungan Hukum Bagi Rakyat Indonesia, PT. Bina Ilmu, Surabaya: 1987.

Setya Wahyudi, Implementasi Ide Diversi dalam Pembaharuan Sistem Peradilan Anak di Indonesia, Genta Publising, Yogyakarta, 2011.

Soerjono Soekanto, Faktor-Faktor yang Mempengaruhi Penegakan Hukum, PT. Raja GrafindoPersada, Jakarta, 2008.

Soerjono Soekanto, Penegakan Hukum, Bina Cipta, Bandung, 1983.

Waluyadi, Hukum Perlindungan Anak, Mandar Maju, Bandung, 2009. 
B. Jurnal

Alex Andreas, T. P. (2016). Implementasi Restorative Justice Dalam UU No 11 Tahun 2012 Tentang Sistem Peradilan Pidana Anak. Diponegoro Law Journal. Vol. 5. No. 3. https://ejournal3.undip.ac.id/index.php/dlr/article/view/12899/12502.

Danielt, R. T. (2014). Penerapan Restorative Justice Terhadap Tindak Pidana Anak Pencurian Oleh Anak Di Bawah Umur. Jurnal Lex Et Societatis. Vol. II. No. 6 , 16. https://ejournal.unsrat.ac.id/index.php/lexetsocietatis/article/view/5364/4872.

Hertanto, I. (2018). Penegakan Hukum Tindak Pidana Ringan Oleh Polri Melalui Pendekatan Restorative Justice (Studi Di Wilayah Hukum Polres Cilacap) . Jurnal Idea Hukum. Vol. 4. No. $\quad 1 \quad, \quad 898 . \quad$ http://jih.fh.unsoed.ac.id/index.php/jih/article/view/71/pdf_20. http://dx.doi.org/10.20884/1.jih.2018.4.1.71.

Lukman, D. R. (2016). Konsep Restorative Justice Dalam Undang-Undang Ri Number 11 Tahun 2012 Tentang Sistem Peradilan Pidana Anak. Jurnal Ius Kajian Hukum Dan Keadilan. Vol. 2. No. $6 . \quad$ http://jurnalius.ac.id/ojs/index.php/jurnalIUS/article/view/207/181 http://dx.doi.org/10.12345/ius.v3i7.207.

Pradityo, R. (2016). Restorative Justice Dalam Sistem Peradilan Pidana Anak. Jurnal Hukum Dan Peradilan. Vol. $\quad 5 . \quad$ No. 3 . http://www.jurnalhukumdanperadilan.org/index.php/jurnalhukumperadilan/article/view/25. http://dx.doi.org/10.25216/JHP.5.3.2016.319-330.

Prasetyo, T. (2015). Penerapan Diversi Terhadap Tindak Pidana Anak Dalam Sistem Peradilan Pidana Anak. Jurnal Refleksi Hukum. Vol. $1 . \quad$ No. 9. https://ejournal.uksw.edu/refleksihukum/article/view/432/291. https://doi.org/10.24246/jrh.2015.v9.i1.p1-14.

Putri, E. I. (2018). Begal Anak; Pemenuhan Hak dan Lembaga Pembinaan Khusus Anak Kelas II A Bandar Lampung. Jurnal Cepalo, 2 (2). https://jurnal.fh.unila.ac.id/index.php/cepalo/article/view/1764/1480. https://doi.org/10.25041/cepalo.v2no2.1764.

Putri, I. T. (2015). Penyelesaian Tindak Pidana Lalu Lintas Melalui Pendekatan Restorative Justice Sebagai Dasar Penghentian Penyidikan dan Perwujudan Asas Keadilan dalam Penjatuhanh Putusan. Jurnal Padjajaran Ilmu Hukum. Vol. $2 . \quad$ No. 1. http://jurnal.unpad.ac.id/pjih/article/view/7178/3345. https://doi.org/10.22304/pjih.v2n1.a9.

Renita Dharma Pratiwi, M. A. (2019). Kendala Penerapan Prinsip Restorative Justice Dalam Perkara Tindak Pidana Anak. Jurnal Lex Suprema. Vol. 1. No. 2 , 5. https://jurnal.law.unibabpn.ac.id/index.php/lexsuprema/article/view/208/pdf.

Sari, M. A. (2013). Diversi Dalam Sistem Peradilan Pidana Anak Di Indonesia. Udayana Master Law Journal. Vol. 2. No. 1. https://ojs.unud.ac.id/index.php/jmhu/article/view/4439/3359. https://doi.org/10.24843/JMHU.2013.v02.i01.p05.

Sosiawan, U. M. (2016). Perspektif Restorative Justice Sebagai Wujud Perlindungan Anak Yang Berhadapan Dengan Hukum. Jurnal Penelitian Hukum De Jure. Vol. 16. No. 4, 426. https://ejournal.balitbangham.go.id/index.php/dejure/article/view/197/60. http://dx.doi.org/10.30641/dejure.2016.V16.425-438.

Utami, P. R. (2018). Konsep Diversi Dan Restorative Justice Sebagai Pergeseran Tanggung Jawab Pidana Pada Sistem Peradilan Pidana Anak. Volksgeist: Jurnal Ilmu Hukum Dan $\begin{array}{lllllll}\text { Konstitusi. } & \text { Vol. } & 1 & \text { No. } & 1 & 99 .\end{array}$ http://ejournal.iainpurwokerto.ac.id/index.php/volksgeist/article/view/1691/1268.

Yusi Permatasari, Y. P. (2019). Kendala Dalam Pelaksanaan Penegakan Hukum Terhadap Praktik Paranormal Sebagai Tindak Pidana. Jurnal Hukum Adigama. Vol. 2. No. 2. https://journal.untar.ac.id/index.php/adigama/article/view/2282/1334. http://dx.doi.org/10.24912/adigama.v1i1.2282.

Putri, Miszuarty. "Pelaksanaan Restitusi Bagi Anak Yang Menjadi Korban Tindak Pidana Sebagai Bentuk Pembaruan Hukum Pidana Berdasarkan Peraturan Pemerintah Nomor 43 Tahun 2017." Soumatera Law Review 2, no. 1, May 1, 2019: 115-34. https://www.neliti.com/publications/284750/pelaksanaan-restitusi-bagi-anak-yang-menjadikorban-tindak-pidana-sebagai-bentuk https://doi.org/10.22216/soumlaw.v2i1.3567.g1347. 
Pendi Wibison. "Penerapan Tindakan Diversi Dalam Proses Penyidikan Tindak Pidana Terhadap Tersangka Anak Di Polres Sukoharjo (Studi Kasus An. Ricky Hernawan).” Accessed July 8, 2020 . https://journal.akpol.ac.id/index.php/apsrj/article/view/108/66 http://journal.akpol.ac.id/index.php/apsrj/article/view/108/66.

C. Undang-udang

Undang-Undang Dasar 1945 Hasil Amandemen ke 4.

Undang-Undang Nomor 8 Tahun 1981 tentang Kitab Undang-Undang Hukum Acara Pidana

Undang-Undang Nomor 2 Tahun 2002 tentang Kepolisian RI;

Undang-Undang Nomor 16 Tahun 2004 tentang Kejaksaan RI.

Undang-Undang Nomor 48 Tahun 2009 tentang Kekuasaan Kehakiman RI.

Undang-Undang Nomor 35 Tahun 2014 tentang Perubahan atas Undang-Undang Nomor 23 tahun 2002 tentang Perlindungan Anak.

Undang-Undang Nomor 11 Tahun 2012 tentang Sistem Peradilan Anak.

Peraturan Pemerintah Nomor 27 Tahun 1983 Jo Peraturan Pemerintah Nomor 58 Tahun 2010 jo Peraturan Pemerintah Nomor 92 Tahun 2015 tentang pelaksanaan KUHAP.

Peraturan Jaksa Agung No. 006/A/J.A/2015 tentang Pedoman Pelaksanaan Diversi Pada Tingkat Penuntutan. 
